\title{
Genetic Analysis of Milk Urea Nitrogen and Lactose and Their Relationships with Other Production Traits in Canadian Holstein Cattle
}

\author{
F. Miglior, ${ }^{\star} \dagger^{1}$ A. Sewalem, ${ }^{\star} \dagger$ J. Jamrozik, $\ddagger$ J. Bohmanova, $\neq$ D. M. Lefebvre,§ and R. K. Moore§ \\ *Agriculture and Agri-Food Canada-Dairy and Swine Research and Development Centre, Sherbrooke, Quebec, Canada, J1M 1 Z3 \\ †Canadian Dairy Network, Guelph, Ontario, Canada, N1G T42 \\ ¥Centre for the Genetic Improvement of Livestock, University of Guelph, Guelph, Ontario, Canada, N1G 2W1 \\ §Valacta, Ste-Anne-de-Bellevue, Quebec, Canada, H9X 3R4
}

\section{ABSTRACT}

The objective of this research was to estimate heritabilities of milk urea nitrogen (MUN) and lactose in the first 3 parities and their genetic relationships with milk, fat, protein, and SCS in Canadian Holsteins. Data were a random sample of complete herds $(60,645$ test day records of 5,022 cows from 91 herds) extracted from the edited data set, which included 892,039 test-day records of 144,622 Holstein cows from 4,570 herds. A test-day animal model with multiple-trait random regression and the Gibbs sampling method were used for parameter estimation. Regression curves were modeled using Legendre polynomials of order 4. A total of 6 separate 4-trait analyses, which included MUN, lactose, or both (yield or percentage) with different combinations of production traits (milk, fat and protein yield, fat and protein percentages, and somatic cell score) were performed. Average daily heritabilities were moderately high for MUN (from 0.384 to 0.414 ), lactose kilograms (from 0.466 to 0.539 ), and lactose percentage (from 0.478 to 0.508 ). Lactose yield was highly correlated with milk yield (0.979). Lactose percentage and MUN were not genetically correlated with milk yield. However, lactose percentage was significantly correlated with somatic cell score $(-0.202)$. The MUN was correlated with fat $(0.425)$ and protein percentages (0.20). Genetic correlations among parities were high for MUN, lactose percentage, and yield. Estimated breeding values (EBV) of bulls for MUN were correlated with fat percentage EBV (0.287) and EBV of lactose percentage were correlated with lactation persistency EBV (0.329). Correlations between lactose percentage and MUN with fertility traits were close to zero, thus diminishing the potential of using those traits as possible indicators of fertility.

Received July 28, 2006.

Accepted December 22, 2006.

${ }^{1}$ Corresponding author: miglior@cdn.ca
Key words: lactose, milk urea nitrogen, genetic parameter

\section{INTRODUCTION}

Valacta, the DHI organization responsible for milk recording in the province of Quebec, has been collecting data for MUN since 1997 in approximately two-thirds of herds enrolled in traditional milk recording. In 2001, Valacta also started collecting data for lactose in approximately one-third of milk-recorded farms. Phenotypic information of MUN and lactose is sent back to farmers for management purposes. The MUN is generally used as a noninvasive approach to monitor the animal's protein status and the efficiency of nitrogen utilization (Moore and Varga, 1986; Broderick and Clayton, 1997; Jonker et al., 1998; Eicher et al., 1999). Analysis of lactose was introduced by Valacta to include this trait in the calculation of the energy value of milk for the purpose of establishing energy requirements for feeding recommendations.

Literature regarding genetic parameters for MUN and lactose, and their relationships with other production traits in dairy cattle, is scarce. Concentration of MUN in Ontario herds has been shown to be heritable with low genetic correlations with production traits (Wood et al., 2003). In the study by Wood et al. (2003), heritabilities of MUN for the first 3 parities ranged between 0.44 to 0.59 , and genetic correlations with production traits were close to zero in parities 1 and 3 and slightly positive in parity 2 . Lower heritabilities for MUN have been found in 2 US studies (Vallimont et al., 2003; Mitchell et al., 2005). Both studies found greater heritabilities when MUN was analyzed by midinfrared spectroscopy than with wet chemistry. Wet chemistry methods directly measure urea nitrogen in milk, whereas infrared MUN values are calculated with prediction equations that use spectrum analyses. Mitchell et al. (2005) found a low positive genetic correlation between wet chemistry and midinfrared MUN (0.38 
and 0.23 , in first and second parity, respectively). Two recent investigations from the Netherlands found heritability values for midinfrared MUN of 0.14 (Stoop et al., 2006) and of 0.22 (de Roos and de Jong, 2006). Stoop et al. (2006) used a fixed regression test-day model on a relatively small data set of first parity cows, whereas de Roos and de Jong (2006) used a random regression test-day model on a much larger data set of multiparous cows. Heritability of 0.23 was found for MUN by Gredler et al. (2006), using a multiple-trait animal model for MUN, BCS, days to first service, and fat:protein ratio.

Lactose percent has been reported to be highly heritable (0.53), according to a study in Holstein cows from Michigan (Welper and Freeman, 1992). The Michigan study included a relative large number of first-lactation cows $(>5,000)$, and a lactation sire model was implemented to estimate variance components. Welper and Freeman (1992) found that lactose yield was less heritable (0.26) than, but highly correlated with, milk yield traits, and negatively correlated with milk content traits, whereas lactose percentage followed the opposite pattern. Stoop et al. (2006) found a higher heritability for lactose yield (0.47). They also estimated genetic correlations among various production traits. Lactose yield was highly correlated with fat and protein yield (0.58 and 0.86 , respectively) and less correlated with MUN (0.22).

Miglior et al. (2006) found a statistically significant association between lactose percentage and MUN in first lactation with functional survival in Canadian Ayrshire and Holstein cows. In particular, Holstein cows were at a decreasing relative risk of being culled with increasing levels of MUN or lactose percentage. Miglior et al. (2006) concluded that the significant association between longevity with MUN and lactose was likely indirect because both traits have been found to be statistically associated with health and fertility status of cows, both of which are associated with longevity.

The underlying motivation for the study was the desire to assess the feasibility of routine estimation EBV for lactose and MUN and to explore their potential as indicator traits for female fertility by estimating their relationship with EBV of other economically important traits. In addition, we wanted to confirm previous findings on MUN by Wood et al. (2003) by using a larger data set and an improved model, as well as to estimate genetic parameters for lactose (yield and percentage), a trait for which literature is scarce. Therefore, the specific objectives of this research were to estimate a) heritabilities of MUN and lactose (yield and percentage) in the first 3 parities, b) their genetic relationships with milk, fat, protein, and SCS, c) breeding values for MUN and lactose percentage in Canadian Holsteins, and d) correlations between bull EBV for MUN and lactose with other traits of interest.

\section{MATERIALS AND METHODS}

Test-day records collected from 2001 to 2004 were provided by Valacta for Holstein cows from Quebec farms. The data included animal registration number, herd, calving date, test date, milk yield, fat, protein and lactose percentages, SCC, MUN concentration, number of milkings per day, and a flag indicating supervised/unsupervised control. Full pedigree records were provided by Canadian Dairy Network (Guelph, Canada). All samples were analyzed by midinfrared spectroscopy using Fossomatic 4000 milk analysers (Foss Electric, Hillerød, Denmark) calibrated (wavelength = $9.6 \mu \mathrm{m}$ ) weekly. Calibration samples were analyzed for anhydrous lactose by HPLC (IDF Standard 198/ISO 22662) and for MUN by pH difference (IDF Standard 195/ISO 14637; International Committee for Animal Recording, 2006).

Records from DIM $<5$ and $>305 \mathrm{~d}$ were eliminated. The SCC were log-transformed to SCS. Only records from the first 3 parities that had data for all production traits on a given test day, including lactose and MUN, were kept. Within cow, if parity 3 was present, parities 1 and 2 were also present, and if parity 2 was present, parity 1 was also present. Herds were required to have a minimum of 20 cows in the data set to be included in the analysis ( $\sim 5$ cows per year). The final edited data set included 892,039 test day records from 144,622 cows from 4,570 herds. To estimate variance components, a random sample of complete herds was extracted from the edited data set. A total of 5,022 cows from 91 herds (average 55 cows/herd) with 60,645 test-day records were randomly selected. The total number of animals (cows with own records + pedigree) included 15,532 animals.

Covariance components were estimated by Bayesian methods with Gibbs sampling using 6 separate 4-trait random regression test-day models. Custom-written software was used for the analysis. Analyzing all 9 traits in one model was computationally very demanding, and the option of several analyses using smaller number of traits was therefore chosen. The six 4-trait analyses were performed for the following group of traits: 1) Milk, lactose percentage, MUN, SCS; 2) Milk, lactose (kg), MUN, SCS; 3) Fat percentage, lactose percentage, MUN, SCS; 4) Protein percentage, lactose percentage, MUN, SCS; 5) Milk, fat (kg), protein (kg), SCS; and 6) Milk, fat percentage, protein percentage, SCS.

The model for a single trait (milk, fat, protein, SCS, MUN, or lactose) can be expressed in matrix notation by the equation 
Table 1. Descriptive statistics of test-day records in complete edited data set

\begin{tabular}{|c|c|c|c|c|c|c|c|c|c|c|c|c|c|c|}
\hline \multirow[b]{2}{*}{ Parity } & \multirow{2}{*}{$\begin{array}{l}\text { Test-day } \\
\text { records }\end{array}$} & \multirow[b]{2}{*}{ Cows } & \multicolumn{2}{|c|}{ Milk (kg) } & \multicolumn{2}{|c|}{ Fat $\%$} & \multicolumn{2}{|c|}{ Protein \% } & \multicolumn{2}{|c|}{$\mathrm{SCC}(\times 1,000 / \mathrm{mL})$} & \multicolumn{2}{|c|}{ MUN (mg/dL) } & \multicolumn{2}{|c|}{ Lactose $(\%)$} \\
\hline & & & Mean & SD & Mean & SD & Mean & SD & Mean & SD & Mean & SD & Mean & SD \\
\hline 1 & 507,761 & 144,622 & 27.0 & 6.4 & 3.83 & 0.68 & 3.30 & 0.32 & 184 & 574 & 10.73 & 3.34 & 4.69 & 0.18 \\
\hline 2 & 273,452 & 75,924 & 31.7 & 9.1 & 3.79 & 0.72 & 3.30 & 0.35 & 244 & 655 & 11.22 & 3.38 & 4.57 & 0.22 \\
\hline 3 & 110,826 & 31,900 & 33.5 & 9.7 & 3.79 & 0.73 & 3.26 & 0.35 & 309 & 782 & 11.16 & 3.31 & 4.52 & 0.24 \\
\hline Total & 892,039 & 144,622 & 29.2 & 8.2 & 3.81 & 0.70 & 3.29 & 0.33 & 218 & 630 & 10.93 & 3.36 & 4.63 & 0.21 \\
\hline
\end{tabular}

$$
\mathrm{y}_{\mathrm{m}}=\mathrm{H}_{\mathrm{m}} \mathrm{h}_{\mathrm{m}}+\mathrm{X}_{\mathrm{m}} \mathrm{b}_{\mathrm{m}}+\mathrm{W}_{\mathrm{m}} \mathrm{p}_{\mathrm{m}}+\mathrm{Z}_{\mathrm{m}} \mathrm{a}_{\mathrm{m}}+\mathrm{e}_{\mathrm{m}}
$$

where $\mathbf{y}_{\mathbf{m}}$ is a vector of observations from lactations 1 , 2 , and 3 , for trait $\mathrm{m}(\mathrm{m}=1, \ldots, 4), \mathbf{h}_{\mathrm{m}}$ is a vector of fixed herd - test-day effects; $\mathbf{b}_{\mathbf{m}}$ is a vector of fixed regression coefficients for age/parity/season of calving effects (2 seasons and 19 age classes); $\mathbf{p}_{\mathbf{m}}$ is a vector of random regression coefficients for permanent environmental effects; $\mathbf{a}_{\mathbf{m}}$ is a vector of random regression coefficients for animal genetic effects; $\mathbf{e}_{\mathbf{m}}$ is a vector of residuals; and $\mathbf{H}_{\mathrm{m}}, \mathbf{X}_{\mathbf{m}}, \mathbf{W}_{\mathbf{m}}$, and $\mathbf{Z}_{\mathbf{m}}$ are incidence matrices assigning observations to effects.

Regression curves were modeled using Legendre polynomials of order 4 as defined by Jamrozik et al. (2002).

The multiple trait model (4 traits at a time) was

$$
\mathrm{y}=\mathrm{Hh}+\mathrm{Xb}+\mathrm{Wp}+\mathrm{Za}+\mathrm{e}
$$

where $\mathrm{y}=\left[\mathrm{y}_{1}{ }^{\prime}, \ldots, \mathrm{y}_{4}{ }^{\prime}\right]^{\prime}, \mathrm{h}=\left[\mathrm{h}_{1}{ }^{\prime}, \ldots, \mathrm{h}_{4}{ }^{\prime}\right]^{\prime}, \mathrm{b}=\left[\mathrm{b}_{1}{ }^{\prime}, \ldots, \mathrm{b}_{4}{ }^{\prime}\right]^{\prime}$, $\mathrm{p}=\left[\mathrm{p}_{1}{ }^{\prime}, \ldots, \mathrm{p}_{4}{ }^{\prime}\right]^{\prime}, \mathrm{a}=\left[\mathrm{a}_{1}{ }^{\prime}, \ldots, \mathrm{a}_{4}{ }^{\prime}\right]^{\prime}$ and $\mathrm{e}=\left[\mathrm{e}_{1}{ }^{\prime}, \ldots, \mathrm{e}_{4}{ }^{\prime}\right]^{\prime} ; \mathrm{H}=$ $\Sigma^{+} \mathrm{H}_{\mathrm{m}}, \times=\Sigma^{+} \mathrm{X}_{\mathrm{m}}, \mathrm{W}=\Sigma^{+} \mathrm{W}_{\mathrm{m}}$, and $\mathrm{Z}=\Sigma^{+} \mathrm{Z}_{\mathrm{m}}$ (direct sum of matrices).

Expectations and covariance structure for random effects can be described in matrix notation as

$$
\mathrm{E}(\mathrm{y})=\mathrm{Hh}+\mathrm{Xb}, \mathrm{E}(\mathrm{p})=0, \mathrm{E}(\mathrm{a})=0, \mathrm{E}(\mathrm{e})=0
$$

and

$$
\mathrm{V}(\mathbf{p})=\mathbf{I} \otimes \mathbf{P}_{0}, \mathrm{~V}(\mathbf{a})=\mathbf{A} \otimes \mathbf{G}_{0}, \mathrm{~V}(\mathbf{e})=\sum^{+} R^{p, s},
$$

where $\mathbf{A}$ is the additive relationship matrix, and $\mathbf{P}_{0}$ and $\mathbf{G}_{0}$ are $60 \times 60$ covariance matrices for environmental and genetic regression coefficients, respectively. Finally $\mathbf{R}^{p, s}$ are $4 \times 4$ matrices of residual covariances among traits with elements that depend on parity (p) and the interval of DIM (s). These intervals were defined as 5 to 45,46 to 115,116 to 205 , and 206 to 305 DIM. Random effects of the model were assumed to be normally distributed, and the conditional distribution of the data was also normal. In addition, residual effects were assumed to be independent between cows and different DIM. Flat prior distributions were assumed for all fixed effects, and inverted Wishart distributions were used as priors for covariance matrices. Prior values for covariances were as estimated previously from Holstein data (Muir et al., 2004), and they were used with minimal number of degrees of freedom. Posterior means of (co)variance components were estimated using 90,000 samples after a burn-in of 10,000 samples for each 4 -trait model. Daily heritability was defined as a ratio of genetic variance to the sum of genetic, permanent environmental $(\mathbf{P E})$, and residual variances for each DIM from 5 to $305 \mathrm{~d}$, and averaged across the entire lactation for each of the first 3 lactations. Genetic correlations were calculated using (co)variances of the first regression coefficients as described by Wood et al. (2003).

Data for estimation of breeding values included an additional year of calving (2005) and had lower editing restrictions in comparison with criteria used to edit the data set for variance component estimation, as missing traits, parities, or both, were allowed. The data set for breeding value estimation included 1,317,798 test day records from 245,283 cows from 4,691 herds. Breeding

\begin{tabular}{|c|c|c|c|c|c|c|c|c|c|c|c|c|c|c|}
\hline \multirow[b]{2}{*}{ Parity } & \multirow{2}{*}{$\begin{array}{l}\text { Test-day } \\
\text { records }\end{array}$} & \multirow[b]{2}{*}{ Cows } & \multicolumn{2}{|c|}{ Milk (kg) } & \multicolumn{2}{|c|}{ Fat $(\%)$} & \multicolumn{2}{|c|}{ Protein $(\%)$} & \multicolumn{2}{|c|}{$\mathrm{SCC}(\times 1,000 / \mathrm{mL})$} & \multicolumn{2}{|c|}{ MUN (mg/dL) } & \multicolumn{2}{|c|}{ Lactose $(\%)$} \\
\hline & & & Mean & SD & Mean & SD & Mean & SD & Mean & SD & Mean & $\mathrm{SD}$ & Mean & SD \\
\hline 1 & 30,432 & 5,022 & 27.2 & 6.3 & 3.81 & 0.64 & 3.31 & 0.31 & 169 & 496 & 10.63 & 3.39 & 4.71 & 0.17 \\
\hline 2 & 20,599 & 4,658 & 31.9 & 8.9 & 3.78 & 0.67 & 3.31 & 0.34 & 229 & 593 & 11.19 & 3.41 & 4.58 & 0.20 \\
\hline 3 & 9,614 & 3,479 & 33.9 & 9.6 & 3.79 & 0.67 & 3.27 & 0.35 & 286 & 724 & 11.26 & 3.40 & 4.53 & 0.23 \\
\hline Total & 60,645 & 5,022 & 29.9 & 8.3 & 3.80 & 0.66 & 3.31 & 0.33 & 170 & 499 & 10.92 & 3.41 & 4.63 & 0.21 \\
\hline
\end{tabular}
values for milk yield, lactose percentage, MUN, and SCS were estimated using a 4-trait multiple-lactation

Table 2. Descriptive statistics of test-day records in random sample used for variance component estimation 
Table 3. Phenotypic correlations among production traits

\begin{tabular}{lccccrrrr}
\hline Item & $\begin{array}{c}\text { Fat } \\
(\mathrm{kg})\end{array}$ & $\begin{array}{c}\text { Protein } \\
(\mathrm{kg})\end{array}$ & $\begin{array}{c}\text { Fat } \\
(\%)\end{array}$ & $\begin{array}{c}\text { Protein } \\
(\%)\end{array}$ & \multicolumn{1}{c}{ SCS } & MUN & $\begin{array}{c}\text { Lactose } \\
(\mathrm{kg})\end{array}$ & $\begin{array}{c}\text { Lactose } \\
(\%)\end{array}$ \\
\hline Milk & 0.787 & 0.936 & -0.362 & -0.520 & -0.083 & -0.031 & 0.989 & 0.252 \\
Fat (kg) & & 0.805 & 0.260 & -0.250 & -0.058 & 0.083 & 0.771 & 0.161 \\
Protein (kg) & & & -0.238 & -0.205 & -0.062 & -0.011 & 0.921 & 0.208 \\
Fat (\%) & & & & 0.470 & 0.045 & 0.182 & -0.370 & -0.168 \\
Protein (\%) & & & & & 0.093 & 0.082 & -0.529 & -0.248 \\
SCS & & & & & -0.100 & -0.110 & -0.227 \\
MUN & & & & & & -0.042 & -0.072 \\
Lactose (kg) & & & & & & & & 0.382 \\
\hline
\end{tabular}

random regression test-day animal model. Variance components estimated with model 1 were used. The model for breeding value estimation was the same as the model used for parameter estimation with the addition of genetic groups, defined by country, sex, and year of birth. Pearson correlations between EBV of all traits evaluated in Canada with lactose percentage and MUN EBV were then estimated for a group of bulls that a) were born after 1990, b) had at least 20 daughters with lactose and MUN records, and c) had an official EBV for all other traits evaluated. It should be noted that EBV for lactose percentage and MUN were obtained using data from Quebec herds only (42\% of milk recorded cows), whereas EBV for all other traits originated from national evaluations.

\section{RESULTS AND DISCUSSION}

Descriptive statistics of the complete edited data set $(\mathrm{n}=144,622)$ and of the random sample data set used for parameter estimation $(n=5,022)$ for all production traits by parity are shown in Tables 1 and 2 , respectively. Means and variances for all traits were practically the same between data sets. The sample for parameter estimation can therefore be considered a representative sample of the data. Table 3 shows raw phenotypic correlations among all traits in the original edited data set. Phenotypically, MUN had a low correlation with all traits, whereas lactose percentage was

Table 4. Average heritabilities by parity

\begin{tabular}{lccc}
\hline & \multicolumn{3}{c}{ Parity } \\
\cline { 2 - 4 } Item & First & Second & Third \\
\hline Milk & 0.518 & 0.431 & 0.468 \\
Fat $(\mathrm{kg})$ & 0.369 & 0.350 & 0.362 \\
Protein $(\mathrm{kg})$ & 0.423 & 0.392 & 0.410 \\
Fat $(\%)$ & 0.555 & 0.533 & 0.543 \\
Protein $(\%)$ & 0.576 & 0.561 & 0.586 \\
SCS & 0.189 & 0.272 & 0.338 \\
MUN & 0.394 & 0.384 & 0.414 \\
Lactose $(\mathrm{kg})$ & 0.539 & 0.466 & 0.490 \\
Lactose $(\%)$ & 0.478 & 0.506 & 0.508 \\
\hline
\end{tabular}

positively correlated with yield traits and negatively correlated with fat and protein percentages as well as with SCS. Lactose yield followed the same pattern as lactose percentage but with much higher phenotypic correlations with yield traits. Phenotypic correlation between lactose yield and percentage was moderate and positive (0.382).

Heritabilities and correlations for the same trait-pair combinations were averaged across separate 4-trait analyses. Original heritabilities and correlations (genetic and permanent environment) that resulted from the 6 separate 4-trait analyses are in the Appendix. Average heritabilities for all traits and for each parity are presented in Table 4 . Heritabilities for lactose yield and percentage were high (0.466 to 0.539). Welper and Freeman (1992), using a lactation model, estimated heritability to be 0.26 for lactose yield and 0.53 for lactose percent in Michigan Holstein cows.

Heritabilities for MUN (0.384 to 0.414) were lower than heritabilities for lactose. Wood et al. (2003) estimated heritabilities for MUN in Ontario herds and obtained larger values, ranging from 0.44 to 0.59 . They used the same model as was used in the current study study. However, because of the short period of data collection $(<2 \mathrm{yr})$, lactations 1 to 3 were analyzed separately. The effect of using a shorter time period and only one parity per analysis is that very few (if any) cows with a record also had a dam with a record in the same analysis. In an animal model setting, it is then difficult to disentangle genetic and permanent environmental effects. As a result, the genetic variance and heritability might have been overestimated in Wood et al. (2003), and it may explain the difference in results with the current study.

In the current study, heritability for SCS tended to increase significantly over parities (0.189 to 0.338$)$. No clear pattern was observed across lactations for MUN and lactose (yield and percentage). As expected, heritabilities for fat (0.533 to 0.555$)$ and protein (0.561 to 0.586 ) percentages were markedly higher than heritabilities for fat $(0.350$ to 0.369$)$ and protein (0.392 to $0.423)$ yield. Overall heritabilities for protein tended 
Table 5. Average correlations among traits (averaged across analyses and lactations), with genetic correlations below diagonal and permanent environmental correlation above diagonal

\begin{tabular}{lrlllllllr}
\hline Item & Milk & $\begin{array}{c}\text { Fat } \\
(\mathrm{kg})\end{array}$ & $\begin{array}{c}\text { Protein } \\
(\mathrm{kg})\end{array}$ & $\begin{array}{c}\text { Fat } \\
(\%)\end{array}$ & $\begin{array}{c}\text { Protein } \\
(\%)\end{array}$ & SCS & MUN & $\begin{array}{c}\text { Lactose } \\
(\mathrm{kg})\end{array}$ & $\begin{array}{c}\text { Lactose } \\
(\%)\end{array}$ \\
\hline Milk & & 0.857 & 0.960 & -0.273 & -0.392 & -0.233 & 0.222 & 0.979 & 0.176 \\
Fat (kg) & 0.566 & & 0.893 & - & - & -0.244 & - & - & - \\
Protein (kg) & 0.894 & 0.684 & & - & - & -0.216 & - & - & - \\
Fat (\%) & -0.494 & - & - & & 0.585 & -0.005 & 0.286 & - & 0.013 \\
Protein (\%) & -0.538 & - & - & 0.659 & & 0.165 & 0.037 & - & 0.080 \\
SCS & 0.001 & -0.045 & 0.014 & -0.109 & 0.009 & & -0.293 & -0.024 & -0.308 \\
MUN & -0.094 & - & - & 0.425 & 0.200 & -0.190 & & -0.092 & 0.299 \\
Lactose (kg) & 0.979 & - & - & - & - & -0.024 & -0.092 & & - \\
Lactose (\%) & 0.096 & - & - & 0.058 & 0.017 & -0.202 & -0.041 & - & \\
\hline
\end{tabular}

to be higher than corresponding heritabilities for fat. Heritabilities for milk yield were very close to heritabilities of lactose $(\mathrm{kg})$.

Table 5 shows genetic and permanent environmental correlations among production traits. Correlations were averaged across lactations and separate 4-trait analyses. Correlations for some trait pairs are missing, as they were not covered by the 6 separate 4 -trait analyses. The MUN had a moderate and positive genetic correlation with fat percentage $(0.425)$ and lower with protein percentage (0.200). The MUN had a negative genetic correlation with SCS (-0.190). Wood et al. (2003) found low genetic correlations of MUN with production traits $(-0.05$ to 0.32$)$. All genetic correlations between lactose percentage and other traits were close to zero, with one exception: a genetic correlation of -0.202 with SCS. Lactose yield seemed to be the same trait genetically as milk yield, as their genetic correlation was very close to 1 (0.979). In a study by Welper and Freeman (1992), lactose percentage was negatively correlated with yield of milk, fat and protein ( -0.16 to -0.30$)$, and SCS $(-0.11)$, and positively correlated with fat and protein percentages (0.16 to 0.29$)$. The same investigation found a small genetic correlation between lactose yield and percentage (0.10); high correlations between lactose yield with milk (0.92), fat (0.68) and protein yield (0.89); and negative correlations with fat $(-0.35)$ and

Table 6. Average genetic correlations among parities within trait

\begin{tabular}{lcccc}
\hline & \multicolumn{3}{c}{ Parity } & $\begin{array}{c}\text { Average } \\
\text { across } \\
\text { parities }\end{array}$ \\
\cline { 2 - 4 } Item & 1 vs. 2 & 1 vs. 3 & 2 vs. 3 & 0.807 \\
\hline Milk & 0.786 & 0.737 & 0.897 & 0.712 \\
Fat (kg) & 0.741 & 0.603 & 0.791 & 0.706 \\
Protein (kg) & 0.739 & 0.585 & 0.793 & 0.933 \\
Fat (\%) & 0.961 & 0.887 & 0.951 & 0.863 \\
Protein (\%) & 0.887 & 0.863 & 0.838 & 0.500 \\
SCS & 0.543 & 0.395 & 0.562 & 0.820 \\
MUN & 0.846 & 0.744 & 0.870 & 0.804 \\
Lactose (kg) & 0.807 & 0.714 & 0.892 & \\
Lactose (\%) & 0.831 & 0.760 & 0.845 & 0.812 \\
\hline
\end{tabular}

protein percentages $(-0.37)$. As expected, negative genetic correlations were found in the current study between milk yield and fat and protein percentages, -0.494 and -0.538 , respectively. No prior estimates from a test-day model are available in the literature for these traits. Using a lactation sire model on Holsteins, Cue et al. (1987) found negative genetic correlations between milk and fat percentage $(-0.285)$ and protein percentage $(-0.560)$.

Average genetic correlations among parities within traits are shown in Table 6. Correlations among parities for MUN, lactose percentage, and yield were quite high like for milk yield. Genetic correlations among parities for SCS were again quite low, confirming previous studies carried out in Canada (Jamrozik et al., 1998; Muir et al., 2004). Genetic correlations among parities for fat and protein percentages were much higher than corresponding values for fat and protein yield. Posterior standard deviations of all estimates (heritability, genetic, and permanent environmental correlations) ranged from 0.015 to 0.116 .

Figures 1 to 3 show the genetic correlations among traits within DIM for parity 1 to 3 , respectively. In first parity, genetic correlations among traits at same DIM tended to be between -0.2 and 0.2 during the full lactation. Genetic correlations between lactose percentage and MUN were close to zero in the first and last part of lactation, and close to -0.2 in the mid part of lactation. In second and third parity, genetic correlations were larger than in first parity, ranging from -0.5 to 0.5 , with higher correlations in the last part of the lactation. Genetic correlations between lactose percentage and MUN in second and third parity were close to -0.2 in the first half of lactation and close to -0.4 in the second half of lactation. Table 7 shows residual correlations, within parity and DIM period, among milk, lactose percentage, MUN, and SCS. Residual correlations were generally small. Correlations were moderate and positive between milk and lactose percentage, with the largest being in the first period of second parity. Corre- 
Table 7. Residual correlations among traits, within parity and DIM period (milk, lactose percentage, MUN, and SCS)

\begin{tabular}{|c|c|c|c|c|c|c|c|c|c|c|c|c|}
\hline \multirow[b]{2}{*}{ Item } & \multicolumn{3}{|c|}{$\begin{array}{l}\text { First period } \\
\text { (5 to } 45 \text { DIM) }\end{array}$} & \multicolumn{3}{|c|}{$\begin{array}{l}\text { Second period } \\
\text { (46 to } 115 \mathrm{DIM})\end{array}$} & \multicolumn{3}{|c|}{$\begin{array}{c}\text { Third period } \\
\text { (116 to } 265 \text { DIM) }\end{array}$} & \multicolumn{3}{|c|}{$\begin{array}{c}\text { Fourth period } \\
\text { (366 to } 305 \text { DIM) }\end{array}$} \\
\hline & Lactose & MUN & SCS & Lactose & MUN & SCS & Lactose & MUN & SCS & Lactose & MUN & SCS \\
\hline Milk & 0.377 & -0.004 & -0.163 & 0.145 & -0.060 & -0.105 & 0.109 & -0.119 & -0.109 & 0.130 & -0.217 & -0.111 \\
\hline Lactose & & -0.044 & -0.362 & & -0.033 & -0.201 & & 0.006 & -0.234 & & -0.066 & -0.272 \\
\hline MUN & & & -0.072 & & & -0.072 & & & -0.087 & & & -0.024 \\
\hline \multicolumn{13}{|c|}{ Second parity } \\
\hline MUN & & & -0.111 & & & -0.124 & & & -0.131 & & & -0.003 \\
\hline \multicolumn{13}{|c|}{ Third parity } \\
\hline Milk & 0.310 & 0.014 & -0.128 & 0.107 & -0.016 & -0.079 & 0.095 & -0.014 & -0.184 & 0.174 & -0.234 & -0.063 \\
\hline Lactose & & 0.008 & -0.248 & & 0.039 & -0.208 & & 0.118 & -0.283 & & 0.229 & -0.355 \\
\hline MUN & & & -0.171 & & & -0.096 & & & -0.188 & & & -0.126 \\
\hline
\end{tabular}

lations were consistently negative across parities and periods between lactose percentage and SCS. Residual correlations were also negative but smaller between MUN and SCS, and between milk and SCS. All other residual correlations were close to zero, including those between MUN and lactose percentage.

Figures 4 and 5 show the test-day genetic and PE variances by parity over DIM for lactose percentage and MUN, respectively. Variances were higher in the first month of lactation for both traits in all parities. After the first month of lactation, variances for MUN in all 3 parities tended to be quite similar over the entire lactation period, until the last month when variances were again higher. The same pattern was observed for lactose percentage in first parity, whereas variances for lactose percentage in second and third parities tended to increase linearly in the second half of the lactation. Genetic variances were higher than PE variance across traits and parities. Table 8 includes residual variances by parity and stage of lactation for lactose percentage and MUN. Residual variances in the first period of lactation were higher than the second and third period across parities and traits. Values of residual variances did not change between the second

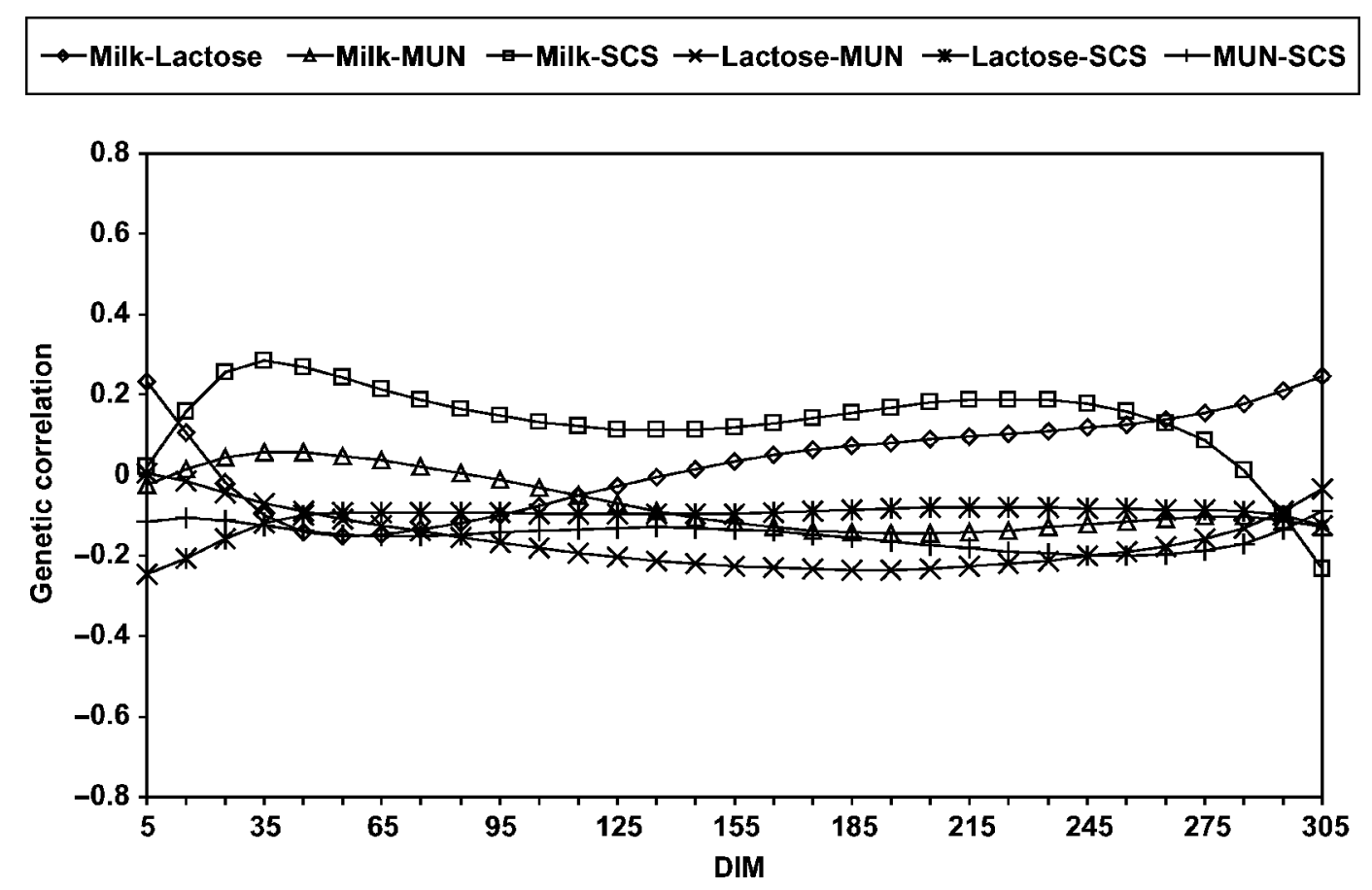

Figure 1. Genetic correlations among milk yield, lactose percentage, MUN, and SCS within DIM for parity 1. 


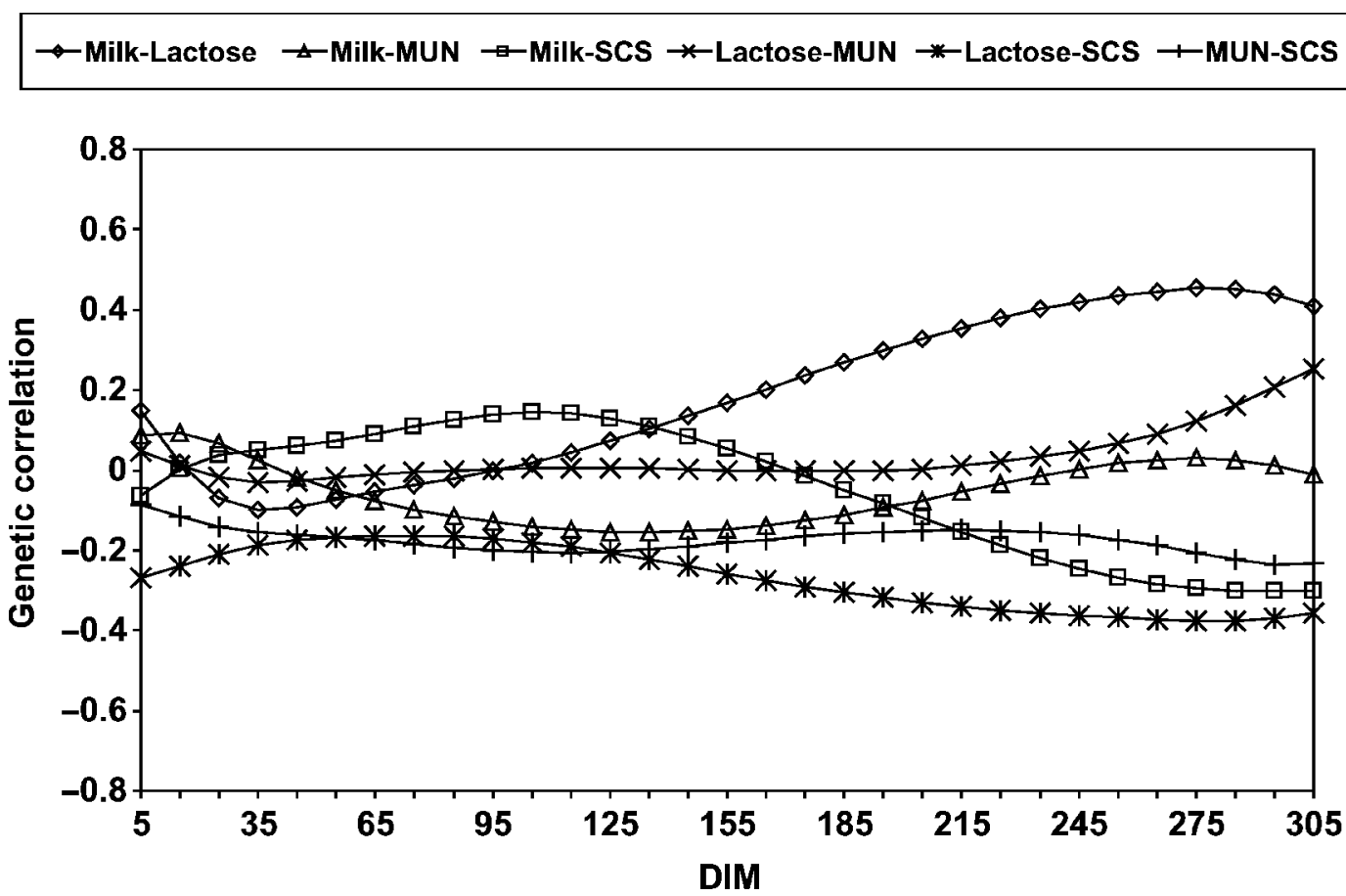

Figure 2. Genetic correlations among milk yield, lactose percentage, MUN, and SCS within DIM for parity 2.

and third period of lactations. Residual variances in the fourth period were similar to the second and third period for lactose percentage in first and second parity, whereas it increased in third parity. Residual variances in the fourth period were lower than the second and third period for MUN in second and third parity,

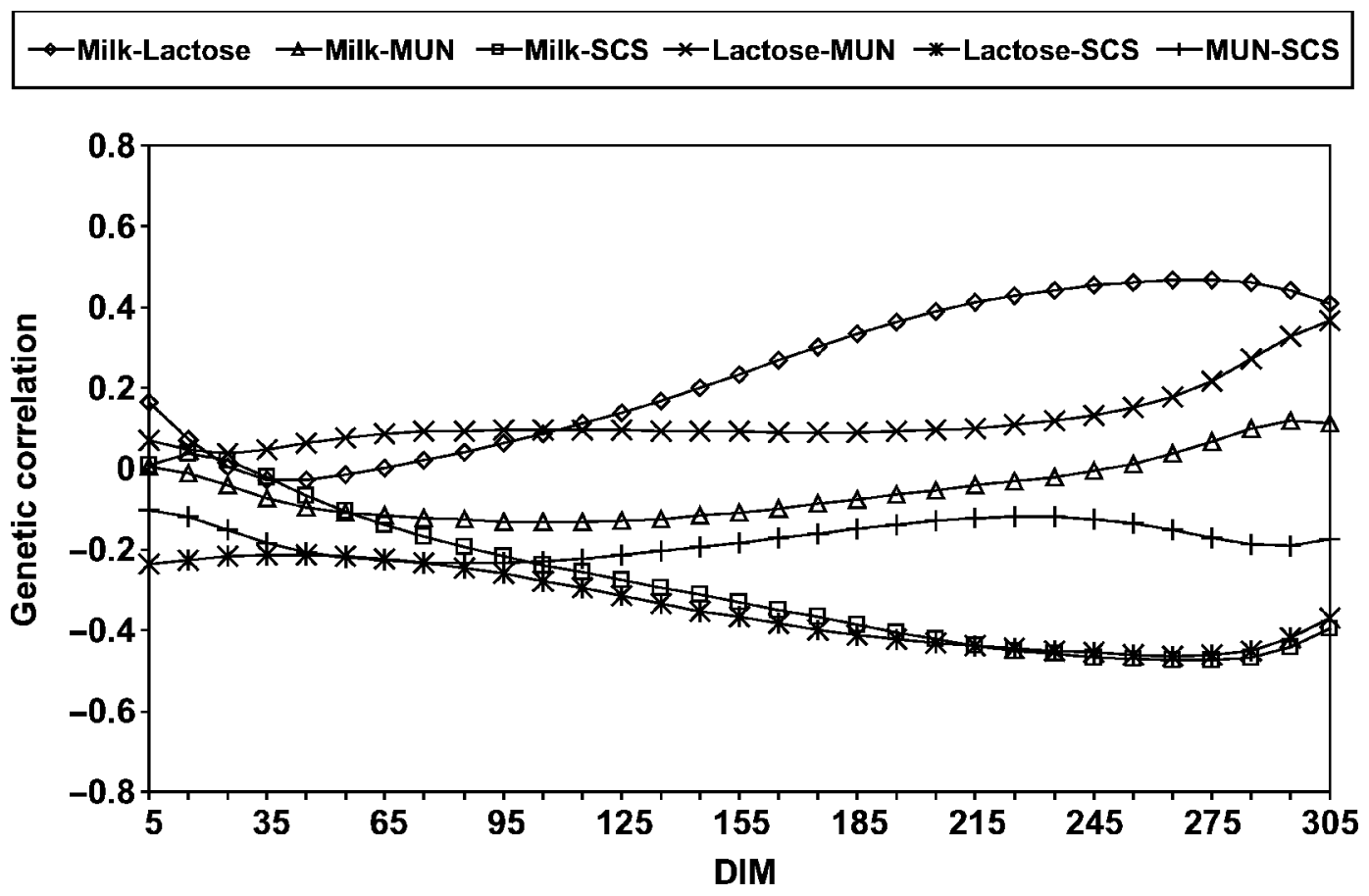

Figure 3. Genetic correlations among milk yield, lactose percentage, MUN, and SCS within DIM for parity 3. 


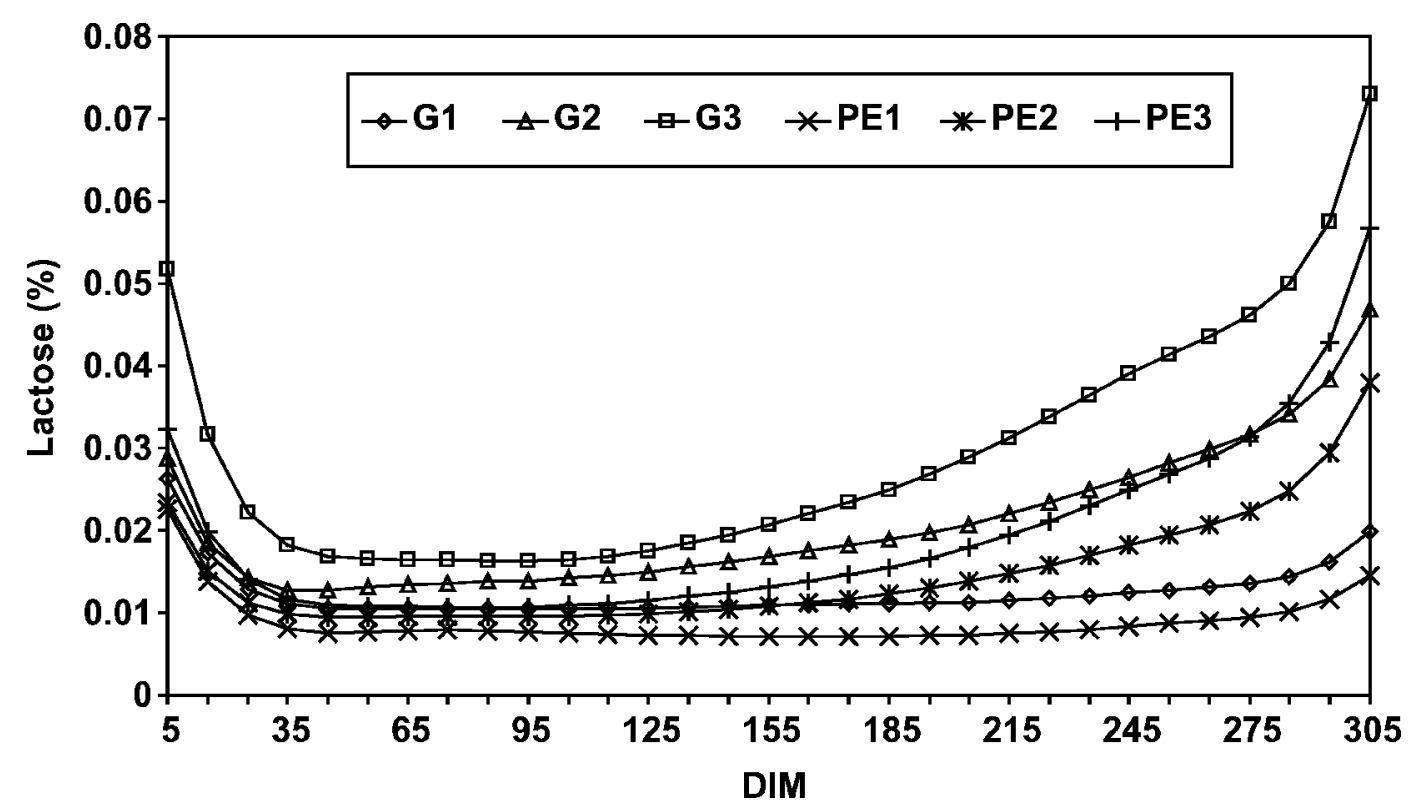

Figure 4. Test-day genetic $(\mathrm{G})$ and permanent environmental (PE) variances for lactose percentage by parity (1 to 3 ) over DIM.

whereas it increased in first parity. Overall, residual variances were lower than genetic variances for both traits, lower than $\mathrm{PE}$ variances for lactose percentage, and greater than $\mathrm{PE}$ variances for MUN.

Table 9 shows bull EBV correlations higher than 0.100 or lower than -0.100 between the trait of interest and MUN and lactose percentage. All production EBV, including lactose percentage and MUN, were expressed on a $305-d$ basis, with equal weights on the 3 parities.
The highest correlation for MUN was with fat percentage (0.287), whereas for lactose percentage the highest correlation was with lactation persistency (0.329), where persistency is defined as expected milk yield on d 280 as a percentage of yield on d 60 in lactation (Schaeffer et al., 2000). Correlations between lactose percentage and MUN with fertility traits were close to zero, thus decreasing the potential of using those traits as possible indicators of fertility.

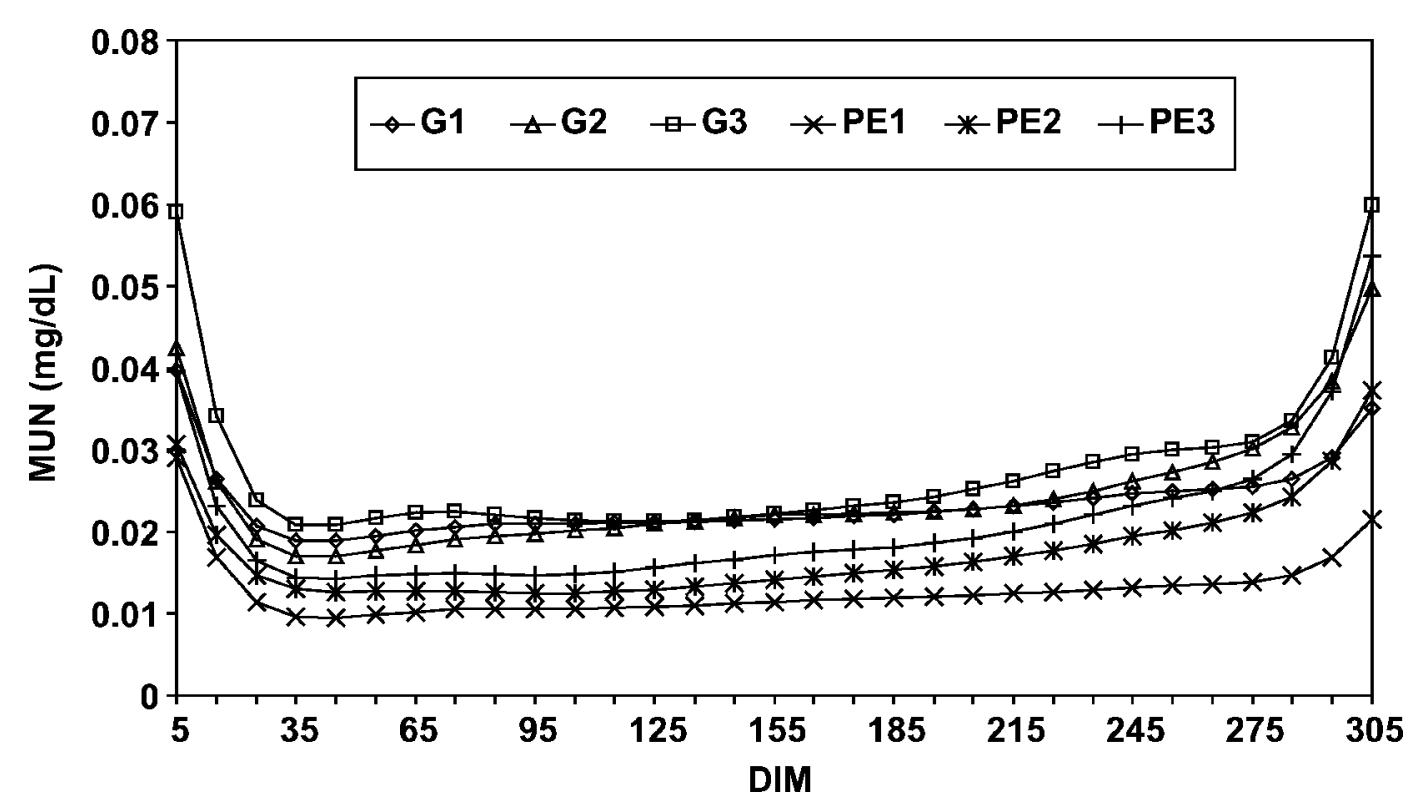

Figure 5. Test-day genetic $(\mathrm{G})$ and permanent environmental (PE) variances for MUN by parity (1 to 3) over DIM. 
Table 8. Residual variances by parity and stage of lactation for lactose percentage and MUN

\begin{tabular}{lcccc}
\hline Item & $\begin{array}{c}\text { First period } \\
\text { (5 to 45 DIM) }\end{array}$ & $\begin{array}{c}\text { Second period } \\
\text { (46 to 115 DIM) }\end{array}$ & $\begin{array}{c}\text { Third period } \\
\text { (116 to 265 DIM) }\end{array}$ & $\begin{array}{c}\text { Fourth period } \\
\text { (366 to 305 DIM) }\end{array}$ \\
\hline $\begin{array}{l}\text { First parity } \\
\text { Lactose (\%) }\end{array}$ & 0.011 & & & \\
$\quad$ MUN (mg/dL) & 0.025 & 0.004 & 0.004 & 0.004 \\
$\begin{array}{l}\text { Second parity } \\
\text { Lactose (\%) }\end{array}$ & 0.008 & 0.020 & 0.020 & 0.023 \\
MUN (mg/dL) & 0.024 & 0.005 & 0.005 & 0.006 \\
Third parity & & 0.021 & 0.019 & 0.017 \\
Lactose (\%) & 0.013 & 0.006 & 0.006 & 0.011 \\
MUN (mg/dL) & 0.022 & 0.019 & 0.017 & 0.016 \\
\hline
\end{tabular}

\section{CONCLUSIONS}

Previous findings of high heritability for MUN in Canadian herds were confirmed by this study. Average daily heritabilities were also moderately high for lactose yield (0.466 to 0.539$)$ and lactose percentage $(0.478$ to 0.508$)$. Lactose yield was highly correlated with milk yield, whereas lactose percentage and MUN were not genetically correlated with milk yield. However, lactose percentage was genetically correlated to SCS $(-0.202)$, whereas MUN was genetically correlated with percentages of fat and protein. Although only data from a single province were included, genetic evaluations of MUN and lactose percentage were feasible using a multitrait random regression test-day model together with milk yield and SCS. Bull EBV of MUN were correlated with fat percentage EBV, whereas lactose percentage EBV were correlated with lactation persistency EBV. Lactose and MUN EBV were not correlated to any EBV of female fertility traits.

\section{ACKNOWLEDGMENTS}

The support and help by Gerrit Kistemaker, Canadian Dairy Network. Authors are also grateful to the 2 anonymous reviewers for their helpful comments.

Table 9. Correlations of bull EBV of MUN and lactose percentage with traits for which the absolute value of the correlation exceeded 0.10

\begin{tabular}{lrlr}
\hline Item & MUN & & $\begin{array}{c}\text { Lactose } \\
(\%)\end{array}$ \\
\hline Milk & -0.106 & SCS & -0.164 \\
Protein (\%) & 0.144 & Mammary system & 0.100 \\
Fat (kg) & 0.208 & Milk & 0.101 \\
Fat (\%) & 0.287 & Median suspensory & 0.112 \\
& & Udder depth & 0.128 \\
& & LPI $^{1}$ & 0.139 \\
& & Lactation persistency & 0.329 \\
\hline
\end{tabular}

${ }^{1}$ Lifetime Profit Index, Canadian selection index.

\section{REFERENCES}

Broderick, G. A., and M. K. Clayton. 1997. A statistical evaluation of animal and nutritional factors influencing concentrations of milk urea nitrogen. J. Dairy Sci. 80:2964-2970.

Cue, R. I., H. G. Monardes, and J. F. Hayes. 1987. Correlations of production traits in first lactation Holstein cows. J. Dairy Sci. 70:2132-2137.

de Roos, A. P. W., and G. de Jong. 2006. Genetic parameters of testday milk urea in Dutch dairy cattle. Proc. 8th World Congr. Genet. Appl. Livest. Prod., Belo Horizonte, MG, Brazil. Communication No. 1:202-396.

Eicher, R., E. Bouchard, and M. Bigras-Poulin. 1999. Factors affecting milk urea nitrogen and protein concentrations in Quebec dairy cows. Prev. Vet. Med. 39:53-63.

Gredler, B., C. Fuerst, and J. Sölkner. 2006. Genetic relationship between body condition score, days to first service and production traits in Austrian Simmental cattle. Proc. 8th World Congr. Genet. Appl. Livest. Prod., Belo Horizonte, MG, Brazil. Communication No. 11:816-1543.

International Committee for Animal Recording. 2006. Guidelines for quality assurance for DHI analyses. http://www.icar.org Accessed Sep. 29, 2006.

Jamrozik, J., L. R. Schaeffer, and F. Grignola. 1998. Genetic parameters for production traits and somatic cell score of Canadian Holsteins with multiple trait random regression model. Proc. 6th World Congr. Genet. Appl. Livest. Prod., Armidale, Australia. 23:303-306.

Jamrozik, J., L. R. Schaeffer, and K. A. Weigel. 2002. Estimates of genetic parameters for single- and multiple-country test-day models. J. Dairy Sci. 85:3131-3141.

Jonker, J. S., R. A. Kohn, and R. A. Erdman. 1998. Using milk urea nitrogen to predict nitrogen excretion and utilization efficiency in lactating dairy cows. J. Dairy Sci. 81:2681-2692.

Miglior, F., A. Sewalem, J. Jamrozik, D. M. Lefebvre, and R. K. Moore. 2006. Analysis of milk urea nitrogen and lactose and their effect on longevity in Canadian dairy cattle. J. Dairy Sci. 89:4886-4894.

Mitchell, R. G., G. W. Rogers, C. D. Dechow, J. E. Vallimont, J. B. Cooper, U. Sander-Nielsen, and J. S. Clay. 2005. Milk urea nitrogen concentration: Heritability and genetic correlations with reproductive performance and disease. J. Dairy Sci. 88:4434-4440.

Moore, D. A., and G. Varga. 1986. BUN and MUN: Urea nitrogen testing in dairy cattle. Compend. Food Anim. 18:712-720.

Muir, B. L., G. Kistemaker, and B. J. Van Doormaal. 2004. Estimation of genetic parameters for the Canadian Test Day Model with Legendre polynomials for Holsteins based on more recent data. (mimeo) A Report to the Genetic Evaluation Board, April, 2004. http://www.cdn.ca/Articles/GEBAPRIL2004/GEBLegendreNew forHolsteinsApril2004.pdf Accessed June 29, 2006.

Schaeffer, L. R., J. Jamrozik, G. J. Kistemaker, and B. J. Van Doormaal. 2000. Experience with a test-day model. J. Dairy Sci. 83:1135-1144.

Stoop, W. M., H. Bovenhuis, and J. A. M. van Arendonk. 2006. Genetic parameters of milk urea and milk production traits. Proc. 8th 
World Congr. Genet. Appl. Livest. Prod., Belo Horizonte, MG, Welper, R. D., and A. E. Freeman. 1992. Genetic parameters for yield Brazil. Communication No. 1:271-386.

Vallimont, J. E., G. W. Rogers, L. A. Holden, M. L. O'Connor, J. B. Cooper, C. D. Dechow, and J. S. Clay. 2003. Milk urea nitrogen and conception rate: A population study using test day records. J. Dairy Sci. 81(Suppl. 1):239. (Abstr.) traits of Holsteins, including lactose and somatic cell score. J. Dairy Sci. 75:1342-1348.

Wood, G. M., P. J. Boettcher, J. Jamrozik, G. B. Jansen, and D. F. Kelton. 2003. Estimation of genetic parameters for concentration of milk urea nitrogen. J. Dairy Sci. 86:2462-2469.

\section{APPENDIX}

Table A1. Parameters for analysis 1 [milk (kg), lactose percentage, MUN, and SCS $]^{1}$

\begin{tabular}{|c|c|c|c|c|c|c|c|c|c|c|c|c|}
\hline Item & \multicolumn{4}{|c|}{ First parity } & \multicolumn{4}{|c|}{ Second parity } & \multicolumn{4}{|c|}{ Third parity } \\
\hline Milk (kg) & 0.536 & 0.061 & 0.250 & -0.266 & 0.449 & 0.049 & 0.003 & -0.007 & 0.281 & 0.033 & -0.140 & 0.157 \\
\hline Lactose $(\%)$ & -0.048 & 0.478 & 0.210 & -0.306 & 0.027 & 0.634 & 0.145 & -0.113 & -0.062 & 0.547 & 0.120 & -0.030 \\
\hline MUN & -0.104 & -0.215 & 0.405 & -0.195 & 0.092 & 0.175 & 0.632 & -0.117 & 0.079 & 0.128 & 0.514 & -0.101 \\
\hline SCS & 0.248 & -0.070 & -0.174 & 0.196 & -0.168 & -0.121 & -0.050 & 0.334 & -0.139 & -0.090 & -0.016 & 0.238 \\
\hline Lactose $(\%)$ & -0.033 & 0.827 & -0.110 & -0.042 & 0.139 & 0.502 & 0.312 & -0.349 & 0.083 & 0.617 & 0.213 & -0.056 \\
\hline MUN & -0.170 & -0.146 & 0.852 & -0.177 & -0.092 & 0.013 & 0.389 & -0.334 & 0.116 & 0.139 & 0.659 & -0.177 \\
\hline SCS & 0.150 & -0.071 & -0.098 & 0.520 & 0.005 & -0.255 & -0.205 & 0.262 & -0.154 & -0.140 & -0.193 & 0.379 \\
\hline \multicolumn{13}{|l|}{ Third parity } \\
\hline Milk (kg) & 0.780 & -0.001 & -0.127 & 0.165 & 0.954 & 0.114 & -0.126 & 0.022 & 0.467 & 0.209 & 0.195 & -0.096 \\
\hline Lactose $(\%)$ & 0.013 & 0.746 & -0.128 & -0.010 & 0.197 & 0.855 & -0.046 & -0.183 & 0.197 & 0.515 & 0.380 & -0.242 \\
\hline MUN & -0.192 & -0.112 & 0.754 & -0.152 & -0.094 & 0.047 & 0.829 & -0.197 & -0.082 & 0.085 & 0.405 & -0.362 \\
\hline
\end{tabular}

${ }^{1}$ Average daily heritabilities on diagonal, genetic correlations below diagonal, and permanent environment correlations above diagonal.

Table A2. Parameters for analysis 2 [milk (kg), lactose (kg), MUN, and SCS $]^{1}$

\begin{tabular}{|c|c|c|c|c|c|c|c|c|c|c|c|c|}
\hline Item & \multicolumn{4}{|c|}{ First parity } & \multicolumn{4}{|c|}{ Second parity } & \multicolumn{4}{|c|}{ Third parity } \\
\hline \multicolumn{13}{|l|}{ First parity } \\
\hline Milk (kg) & 0.544 & 0.980 & 0.255 & -0.260 & 0.321 & 0.295 & 0.025 & -0.039 & 0.310 & 0.284 & -0.039 & 0.118 \\
\hline Lactose (kg) & 0.983 & 0.539 & 0.246 & -0.314 & 0.316 & 0.313 & 0.028 & -0.062 & 0.285 & 0.277 & -0.035 & 0.104 \\
\hline MUN & -0.137 & -0.154 & 0.361 & -0.214 & 0.068 & 0.069 & 0.659 & -0.125 & 0.040 & 0.044 & 0.532 & -0.072 \\
\hline Milk (kg) & 0.828 & 0.818 & -0.099 & 0.193 & 0.463 & 0.986 & 0.217 & -0.304 & 0.407 & 0.374 & 0.020 & 0.002 \\
\hline Lactose (kg) & 0.785 & 0.807 & -0.099 & 0.176 & 0.979 & 0.466 & 0.228 & -0.353 & 0.381 & 0.375 & 0.039 & -0.018 \\
\hline MUN & -0.182 & -0.186 & 0.832 & -0.105 & -0.075 & -0.060 & 0.374 & -0.321 & 0.064 & 0.071 & 0.645 & -0.149 \\
\hline SCS & 0.168 & 0.155 & -0.068 & 0.532 & -0.025 & -0.076 & -0.200 & 0.280 & -0.105 & -0.135 & -0.179 & 0.357 \\
\hline \multicolumn{13}{|l|}{ Third parity } \\
\hline Milk (kg) & 0.727 & 0.718 & -0.112 & 0.109 & 0.888 & 0.866 & -0.084 & -0.085 & 0.478 & 0.976 & 0.181 & -0.161 \\
\hline Lactose (kg) & 0.693 & 0.714 & -0.112 & 0.093 & 0.873 & 0.892 & -0.077 & -0.114 & 0.974 & 0.490 & 0.209 & -0.221 \\
\hline
\end{tabular}

\footnotetext{
${ }^{1}$ Average daily heritabilities on diagonal, genetic correlations below diagonal, and permanent environment correlations above diagonal.
} 
Table A3. Parameters for analysis 3 (fat and lactose percentages, MUN, and SCS) ${ }^{1}$

\begin{tabular}{|c|c|c|c|c|c|c|c|c|c|c|c|c|}
\hline \multirow[b]{2}{*}{ Item } & \multicolumn{4}{|c|}{ First parity } & \multicolumn{4}{|c|}{ Second parity } & \multicolumn{4}{|c|}{ Third parity } \\
\hline & $\begin{array}{l}\text { Fat } \\
(\%)\end{array}$ & $\begin{array}{c}\text { Lactose } \\
(\%)\end{array}$ & MUN & SCS & $\begin{array}{l}\text { Fat } \\
(\%)\end{array}$ & $\begin{array}{c}\text { Lactose } \\
(\%)\end{array}$ & MUN & SCS & $\begin{array}{l}\text { Fat } \\
(\%)\end{array}$ & $\begin{array}{c}\text { Lactose } \\
(\%)\end{array}$ & MUN & SCS \\
\hline Fat $(\%)$ & 0.579 & -0.015 & 0.120 & 0.105 & 0.682 & 0.049 & 0.232 & -0.135 & 0.533 & 0.018 & 0.270 & -0.135 \\
\hline Lactose $(\%)$ & 0.032 & 0.480 & 0.189 & -0.319 & -0.017 & 0.630 & 0.138 & -0.119 & -0.009 & 0.528 & 0.106 & 0.007 \\
\hline MUN & 0.366 & -0.201 & 0.405 & -0.186 & 0.131 & 0.165 & 0.638 & -0.098 & 0.220 & 0.125 & 0.524 & -0.096 \\
\hline SCS & -0.161 & -0.040 & -0.197 & 0.170 & 0.109 & -0.124 & -0.037 & 0.324 & 0.098 & -0.094 & 0.000 & 0.211 \\
\hline \multicolumn{13}{|l|}{ Second parity } \\
\hline Lactose (\%) & 0.024 & 0.832 & -0.100 & -0.036 & 0.035 & 0.510 & 0.306 & -0.352 & 0.048 & 0.639 & 0.221 & -0.082 \\
\hline MUN & 0.383 & -0.127 & 0.853 & -0.206 & 0.402 & 0.022 & 0.395 & -0.315 & 0.306 & 0.149 & 0.681 & -0.192 \\
\hline SCS & -0.021 & -0.067 & -0.126 & 0.586 & -0.065 & -0.243 & -0.232 & 0.267 & -0.078 & -0.174 & -0.205 & 0.399 \\
\hline \multicolumn{13}{|l|}{ Third parity } \\
\hline Fat $(\%)$ & 0.955 & 0.064 & 0.306 & -0.150 & 0.966 & 0.061 & 0.350 & 0.006 & 0.578 & 0.031 & 0.439 & -0.089 \\
\hline Lactose $(\%)$ & 0.055 & 0.766 & -0.115 & -0.014 & 0.058 & 0.841 & -0.033 & -0.153 & 0.107 & 0.507 & 0.368 & -0.262 \\
\hline MUN & 0.509 & -0.084 & 0.769 & -0.209 & 0.530 & 0.057 & 0.831 & -0.200 & 0.506 & 0.109 & 0.426 & -0.357 \\
\hline
\end{tabular}

${ }^{1}$ Average daily heritabilities on diagonal, genetic correlations below diagonal, and permanent environment correlations above diagonal.

Table A4. Parameters for analysis 4 (protein and lactose percentages, MUN, and SCS) ${ }^{1}$

\begin{tabular}{|c|c|c|c|c|c|c|c|c|c|c|c|c|}
\hline Item & \multicolumn{4}{|c|}{ First parity } & \multicolumn{4}{|c|}{ Second parity } & \multicolumn{4}{|c|}{ Third parity } \\
\hline Protein (\%) & 0.621 & 0.150 & -0.036 & 0.165 & 0.500 & 0.064 & 0.125 & -0.027 & 0.591 & 0.076 & 0.154 & -0.040 \\
\hline Lactose (\%) & 0.060 & 0.475 & 0.218 & -0.327 & 0.110 & 0.633 & 0.147 & -0.125 & 0.129 & 0.524 & 0.110 & 0.010 \\
\hline MUN & 0.081 & -0.227 & 0.404 & -0.203 & 0.034 & 0.196 & 0.654 & -0.144 & 0.041 & 0.151 & 0.558 & -0.149 \\
\hline SCS & -0.042 & -0.029 & -0.163 & 0.168 & 0.011 & -0.130 & -0.069 & 0.329 & 0.032 & -0.070 & -0.020 & 0.216 \\
\hline Lactose (\%) & -0.011 & 0.835 & -0.136 & -0.030 & -0.038 & 0.504 & 0.319 & -0.364 & 0.069 & 0.648 & 0.234 & -0.099 \\
\hline MUN & 0.147 & -0.156 & 0.845 & -0.144 & 0.189 & -0.015 & 0.378 & -0.349 & 0.110 & 0.168 & 0.695 & -0.225 \\
\hline SCS & -0.019 & -0.061 & -0.060 & 0.577 & 0.085 & -0.226 & -0.161 & 0.259 & 0.052 & -0.170 & -0.221 & 0.407 \\
\hline \multicolumn{13}{|l|}{ Third parity } \\
\hline Protein (\%) & 0.876 & 0.021 & 0.149 & 0.011 & 0.944 & -0.004 & 0.193 & 0.003 & 0.620 & 0.037 & 0.154 & 0.179 \\
\hline Lactose $(\%)$ & 0.010 & 0.767 & -0.152 & -0.042 & -0.007 & 0.838 & -0.077 & -0.157 & 0.030 & 0.503 & 0.389 & -0.248 \\
\hline MUN & 0.300 & -0.125 & 0.728 & -0.137 & 0.324 & 0.007 & 0.804 & -0.152 & 0.330 & 0.061 & 0.419 & -0.348 \\
\hline
\end{tabular}

\footnotetext{
${ }^{1}$ Average daily heritabilities on diagonal, genetic correlations below diagonal, and permanent environment correlations above diagonal.
} 
Table A5. Parameters for analysis 5 [milk $(\mathrm{kg})$, fat $(\mathrm{kg})$, protein $(\mathrm{kg})$, and SCS ${ }^{1}$

\begin{tabular}{|c|c|c|c|c|c|c|c|c|c|c|c|c|}
\hline \multirow[b]{2}{*}{ Item } & \multicolumn{4}{|c|}{ First parity } & \multicolumn{4}{|c|}{ Second parity } & \multicolumn{4}{|c|}{ Third parity } \\
\hline & $\begin{array}{l}\text { Milk } \\
\text { (kg) }\end{array}$ & $\begin{array}{l}\text { Fat } \\
(\mathrm{kg})\end{array}$ & $\begin{array}{l}\text { Protein } \\
\text { (kg) }\end{array}$ & SCS & $\begin{array}{l}\text { Milk } \\
(\mathrm{kg})\end{array}$ & $\begin{array}{l}\text { Fat } \\
(\mathrm{kg})\end{array}$ & $\begin{array}{l}\text { Protein } \\
\text { (kg) }\end{array}$ & SCS & $\begin{array}{l}\text { Milk } \\
(\mathrm{kg})\end{array}$ & $\begin{array}{l}\text { Fat } \\
(\mathrm{kg})\end{array}$ & $\begin{array}{l}\text { Protein } \\
\text { (kg) }\end{array}$ & SCS \\
\hline Milk (kg) & 0.489 & 0.819 & 0.949 & -0.240 & 0.419 & 0.336 & 0.425 & -0.027 & 0.381 & 0.281 & 0.356 & 0.054 \\
\hline Fat $(\mathrm{kg})$ & 0.556 & 0.369 & 0.872 & -0.181 & 0.343 & 0.476 & 0.407 & -0.098 & 0.358 & 0.456 & 0.405 & -0.052 \\
\hline Protein (kg) & 0.905 & 0.648 & 0.423 & -0.198 & 0.386 & 0.373 & 0.435 & -0.045 & 0.343 & 0.307 & 0.370 & 0.041 \\
\hline SCS & 0.236 & 0.125 & 0.226 & 0.214 & -0.172 & -0.121 & -0.170 & 0.332 & -0.136 & -0.077 & -0.121 & 0.215 \\
\hline Fat $(\mathrm{kg})$ & 0.330 & 0.741 & 0.415 & 0.011 & 0.547 & 0.350 & 0.896 & -0.313 & 0.432 & 0.497 & 0.486 & -0.063 \\
\hline Protein (kg) & 0.651 & 0.445 & 0.739 & 0.173 & 0.887 & 0.681 & 0.392 & -0.285 & 0.488 & 0.415 & 0.523 & 0.010 \\
\hline SCS & 0.175 & 0.167 & 0.202 & 0.518 & 0.000 & -0.057 & 0.005 & 0.283 & -0.129 & -0.143 & -0.122 & 0.384 \\
\hline \multicolumn{13}{|l|}{ Third parity } \\
\hline Milk (kg) & 0.672 & 0.199 & 0.569 & 0.167 & 0.827 & 0.354 & 0.716 & -0.050 & 0.456 & 0.880 & 0.965 & -0.201 \\
\hline Fat (kg) & 0.306 & 0.603 & 0.380 & 0.032 & 0.460 & 0.791 & 0.579 & -0.057 & 0.594 & 0.362 & 0.912 & -0.238 \\
\hline Protein (kg) & 0.518 & 0.275 & 0.585 & 0.171 & 0.698 & 0.468 & 0.793 & -0.079 & 0.890 & 0.724 & 0.410 & -0.166 \\
\hline
\end{tabular}

${ }^{1}$ Average daily heritabilities on diagonal, genetic correlations below diagonal, and permanent environment correlations above diagonal.

Table A6. Parameters for analysis 6 [milk (kg), fat and protein percentages, and SCS $]^{1}$

\begin{tabular}{|c|c|c|c|c|c|c|c|c|c|c|c|c|}
\hline Item & \multicolumn{4}{|c|}{ First parity } & \multicolumn{4}{|c|}{ Second parity } & \multicolumn{4}{|c|}{ Third parity } \\
\hline Milk (kg) & 0.502 & -0.336 & -0.413 & -0.212 & 0.420 & -0.188 & -0.194 & -0.013 & 0.281 & -0.129 & -0.197 & 0.099 \\
\hline Fat $(\%)$ & -0.533 & 0.532 & 0.596 & 0.064 & -0.163 & 0.766 & 0.455 & -0.106 & -0.094 & 0.710 & 0.479 & -0.167 \\
\hline Protein (\%) & -0.576 & 0.643 & 0.532 & 0.153 & -0.197 & 0.474 & 0.631 & -0.029 & -0.170 & 0.395 & 0.653 & -0.103 \\
\hline \multicolumn{13}{|l|}{ Second parity } \\
\hline Fat $(\%)$ & -0.491 & 0.949 & 0.611 & -0.152 & -0.490 & 0.520 & 0.592 & -0.030 & -0.142 & 0.749 & 0.477 & -0.149 \\
\hline Protein (\%) & -0.468 & 0.633 & 0.878 & -0.054 & -0.521 & 0.662 & 0.528 & 0.151 & -0.151 & 0.414 & 0.613 & -0.024 \\
\hline SCS & 0.153 & -0.034 & -0.021 & 0.524 & -0.031 & -0.047 & 0.050 & 0.281 & -0.130 & -0.042 & 0.015 & 0.359 \\
\hline \multicolumn{13}{|l|}{ Third parity } \\
\hline Milk (kg) & 0.768 & -0.507 & -0.510 & 0.128 & 0.917 & -0.494 & -0.495 & -0.034 & 0.469 & -0.206 & -0.298 & -0.156 \\
\hline Fat $(\%)$ & -0.475 & 0.914 & 0.607 & -0.118 & -0.447 & 0.935 & 0.621 & -0.009 & -0.459 & 0.509 & 0.566 & -0.139 \\
\hline Protein (\%) & -0.496 & 0.645 & 0.849 & -0.056 & -0.512 & 0.656 & 0.897 & -0.004 & -0.517 & 0.673 & 0.552 & 0.066 \\
\hline
\end{tabular}

\footnotetext{
${ }^{1}$ Average daily heritabilities on diagonal, genetic correlations below diagonal, and permanent environment correlations above diagonal.
} 